\title{
Assessing the use of frozen pork meat in the manufacture of cooked ham
}

\author{
Francine Gomes Basso LOS ${ }^{1}$, Rosa Cristina PRESTES ${ }^{2}$, Daniel GRANATOํㅗ Deise Rosana Silva SIMÕES ${ }^{1}$, \\ Silvane Souza ROMAN ${ }^{3}$, Ivo Mottin DEMIATE ${ }^{1 *}$
}

\begin{abstract}
This study aimed to evaluate the effects of slow $\left(-18^{\circ} \mathrm{C}\right)$ and fast freezing (liquid nitrogen) of pork meat, and the use of exudate released upon thawing, on the physicochemical, color, rheological, microbiological, histological, and sensory characteristics of cooked ham. The meat samples were frozen at $-18^{\circ} \mathrm{C}$ and thawed after 22 weeks for the production of cooked ham. No significant difference was observed regarding physicochemical, color and microbiological parameters or in sensory acceptance. The hardness and chewiness parameters showed significant differences when compared to the control sample (ham made from chilled meat). Light microscopy of cooked ham samples showed that changes in the tissues were caused by freezing and thawing the meat. The effect of exudate was significant on the sodium content and compression force parameters, but this difference was not perceived in the sensory analysis, confirming that frozen pork meat can be used to produce cooked ham without loss of quality.
\end{abstract}

Keywords: histology; sensory analysis; texture; freezing-thawing.

Practical Application: The use of frozen meat in cooked ham allows flexibility to producers.

\section{Introduction}

The quality of cooked ham depends on the quality of the raw materials, as well as the processing operations employed: brine injection, tumbling, curing and cooking (Casiraghi et al., 2007). Although usually cooked ham is produced with fresh meat, the use of frozen raw material shows the advantages of producing more homogeneous batches from previously selected frozen hams with similar physicochemical characteristics and better control of stock and production levels (Utrera et al., 2012).

Studies have been conducted to confirm the use of frozen/ thawed raw material in cooked ham. Peña et al. (1998) compared physicochemical characteristics and protein profile to demonstrate the possibility of using frozen meat in Spanish cooked ham. The effect of freezing the raw material on color, texture and water holding capacity (WHC) in cooked ham was also studied by Utrera et al. (2012) and Estevez (2011).

The freezing rate determines the size of the ice crystals that are formed, which is a critical factor in minimizing tissue damage by frozen and fluid loss after thawing (Li \& Sun, 2002). At an industrial level it is not common to use exudate thawing in the preparation of meat products, primarily because if the collection of this fluid is performed improperly it increases the risk of microbiological contamination. Most studies regarding the industrialization of meat products with frozen/thawed meat do not clarify the use of the exudate that is released during thawing.

The objective of the present study was to evaluate the effect of slow $\left(-18^{\circ} \mathrm{C}\right)$ and fast freezing (liquid nitrogen) on pork meat and the use of exudate released upon thawing, on the physicochemical, structural (rheological and histological), technological and sensory characteristics of cooked ham.

\section{Materials and methods}

\subsection{Meat freezing}

The pork meat was provided by an inspected slaughterhouse of Ponta Grossa city (Paraná State, Brazil). Hams from Topigs $20^{\mathrm{TM}}$ (Topigs Norsvin, Curitiba PR Brazil), aged 160 days and weighing approximately $100 \mathrm{~kg}$, were deboned after 24 hours of chilling. The skin, bones, soft bones and excess fat were removed manually. The hams were cut into pieces of approximately 150-200 g, and packaged in bags of $0.05 \mathrm{~mm}$ thickness low density polyethylene (LDPE).

The slow freezing was performed in a commercial freezer (Metalfrio, Porto Alegre, RS, Brazil) at $-18{ }^{\circ} \mathrm{C}$ for eight hours. For rapid freezing, the samples were submerged in a tank containing liquid nitrogen at $-196^{\circ} \mathrm{C}$ for about three minutes. After that, the samples were kept frozen at $-18^{\circ} \mathrm{C}$ for 22 weeks, time considered to be appropriate from an industrial standpoint to allow flexibility in the processes of preparation and use of raw materials.

The samples were thawed at $5^{\circ} \mathrm{C}$ (Brasil, 1995), in a refrigerator (Electrolux, Curitiba, PR, Brazil) until they reached $2{ }^{\circ} \mathrm{C}$ in the core (Xia et al., 2009). The volume of exudate released was measured in a graduated cylinder. 


\subsection{Production of cooked ham}

The formulation of cooked ham produced in the present work is shown in Table 1. The ingredients were homogenized in water at $1{ }^{\circ} \mathrm{C}$ by using an industrial blender (Siemsen, Brusque, Brazil) and brine was added to the meat in a $27 \mathrm{~L}$ capacity tumbler (Silveira, Chapeco, Brazil). The tumbling was performed for $6 \mathrm{~h}$ at $22 \mathrm{rpm}$ under refrigeration, followed by curing for $12 \mathrm{~h}$ at $4{ }^{\circ} \mathrm{C}$ (Lachowicz et al., 2003). The samples were packed in polyamide bags (PA) in pieces of approximately $700 \mathrm{~g}$, sealed under $90 \%$ vacuum (Jetvac, São Caetano do Sul, Brazil) and molded into $155 \times 115 \times 90 \mathrm{~mm}$ pieces. Samples were cooked in a water tank (Silveira, Chapeco, Brazil) according to Terra (2000): 30 minutes at $60{ }^{\circ} \mathrm{C}, 30$ minutes at $70{ }^{\circ} \mathrm{C}, 30$ minutes at $80^{\circ} \mathrm{C}$, until reach $72^{\circ} \mathrm{C}$ at the core. After cooking, the samples were cooled at $4{ }^{\circ} \mathrm{C}$. Three replicates were conducted in February, July and September 2013, under the same conditions. The tests were performed by varying the meat freezing methods and the presence or absence of the exudate, according to Table 2. On the assays in which the exudate was used, it was added directly in the tumbler to complete the weight of the meat (meat + exudate $=70 \%$ ). To produce the control treatment $(\mathrm{C})$, chilled meat was collected and trimmed one day before processing.

\subsection{Physicochemical analysis}

The physicochemical composition of the samples of cooked ham was analyzed in triplicate according to the Association of Analytical Chemists (1990) for the following parameters: $\mathrm{pH}$ by

Table 1. Formulation of cooked ham.

\begin{tabular}{lc}
\hline \multicolumn{1}{c}{ Ingredient } & $\%$ \\
\hline Meat or meat + exudate & 70 \\
Water & 23.9 \\
Sodium chloride $^{1}$ & 2.175 \\
95\% isolated soy protein $^{2}$ & 2.0 \\
Saccharose $^{3}$ & 0.5 \\
Sodium tripolyphosphate $^{4}$ & 0.5 \\
kappa-carrageenan $^{5}$ & 0.5 \\
Monosodium glutamate $^{4}$ & 0.2 \\
Sodium erythorbate $^{4}$ & 0.1 \\
Condiment $^{5}$ & 0.08 \\
3\% cochineal carmine dye $^{4}$ & 0.03 \\
Sodium nitrite $^{4}$ & 0.015 \\
\hline
\end{tabular}

Note: supplied by: ${ }^{1}$ Diana Company (Curitiba, PR, Brazil). ${ }^{2}$ ADM Company (Decatur, IL, USA). ${ }^{3}$ União Company (São Paulo, SP, Brazil). ${ }^{4}$ Nutract Company (Chapecó, SC, Brazil) ${ }^{5}$ Doremus Company (Guarulhos, SP, Brazil).

Table 2. Experiments conducted to produce cooked hams' samples.

\begin{tabular}{ccc}
\hline Assays & Freezing method & Exudate \\
\hline SF1 & Slow & Absence \\
SF2 & Slow & Presence \\
FF1 & Fast & Absence \\
FF2 & Fast & Presence \\
C & Chilled meat & Chilled meat \\
\hline
\end{tabular}

Note: SF1 - sample produced with frozen meat by slow process, without exudate; SF2 - sample produced with frozen meat by slow process, with exudate; FF1 - sample produced with frozen meat by fast process $\left(\mathrm{N}_{2}\right)$, without exudate; FF2 - sample produced with frozen meat by fast process, with exudate; $\mathrm{C}$ - sample produced with chilled meat (control). potentiometric method; moisture content, gravimetrically at $105^{\circ} \mathrm{C}$; ash content by incineration at $550^{\circ} \mathrm{C}$ for $6 \mathrm{~h}$ in a muffle furnace, model 2310 (Jung, Blumenau, Brazil); protein content by the Kjeldahl method; lipids by the Soxhlet method; sodium nitrite content by spectrophotometric method and sodium content by nitric-perchloric digestion, followed by reading on a flame photometer, model 7000 (Tecnow, São Paulo, Brazil) (Association of Analytical Chemists, 1990). Water activity was determined at $25^{\circ} \mathrm{C}$ by using an Aqualab device, model 3TE (Decagon Device Inc., Pullman, USA). All chemicals used were of analytical grade (Merck, Darmstadt, Germany).

\subsection{Instrumental color}

The color assessment was performed by reflectance according to the CIE $L^{*} a^{*} b^{*}$ system to measure the parameters $L^{\star}$ (lightness), $a^{\star}$ (redness), $b^{\star}$ (yellowness), $C^{\star}$ (saturation) and $h^{\star}$ (hue). The samples were cut into $2.5 \mathrm{~cm}$ thick slices and seven measurements were performed on each slice using a Mini EZ Scan spectrophotometer, model $4500 \mathrm{~L}$ (HunterLab, Reston, VA, USA) with D65 illuminant and $10^{\circ}$ observation angle.

\subsection{Rheometry}

Instrumental texture analysis was performed in triplicate using a TA.XT plus Universal texturometer (Stable Micro Systems, Godalming, UK) at $20^{\circ} \mathrm{C}$. Texture profile analysis (TPA) was conducted using a P75 cylindrical probe. The samples were diced into $2 \mathrm{~cm}$ cubes and subjected to a dual compression of $20 \%$ at a constant speed of $1.0 \mathrm{~mm} . \mathrm{s}^{-1}$ with a five seconds interval between the first and second compression (Tabilo et al., 1999). The parameters evaluated were: hardness $(\mathrm{N})$, cohesiveness, adhesiveness (N.mm), elasticity ( $\mathrm{mm})$, chewiness (n.mm) and resilience.

To evaluate the shear force the samples were prepared as $1.5 \times 1.5 \times 4.0 \mathrm{~cm}$ pieces and cut using a Warner-Bratzler Blade at $2.0 \mathrm{~mm} . \mathrm{s}^{-1}$. To compression force samples were prepared as $1.5 \times 1.5 \times 2.0 \mathrm{~cm}$ pieces and compressed at $66.67 \%$ of their height with a P36/R probe at a speed of $1.5 \mathrm{~mm} . \mathrm{s}^{-1}$ (Pedroso \& Demiate, 2008).

\subsection{Technological properties}

The technological properties in this study aimed to evaluate the behavior of the samples during processing and their subsequent use in prepared foods, such as frozen and reheated foods for consumption (Pedroso \& Demiate, 2008).

The water holding capacity (WHC) and syneresis were evaluated following Prestes et al. (2012). Freezing losses was performed according to Lee et al. (2002), adapted by Prestes et al. (2013). Samples were prepared with $3 \mathrm{~cm}$ diameter $\times 1 \mathrm{~cm}$ height and were then weighed, wrapped in aluminum foil, and frozen at $-18{ }^{\circ} \mathrm{C}$ for $72 \mathrm{~h}$. After this period, the samples were thawed for $4 \mathrm{~h}$ at $25^{\circ} \mathrm{C}$, wrapped in $12.5 \mathrm{~cm}$ diameter paper filter and pressed for $5 \mathrm{~min}$ with a $2 \mathrm{~kg}$ weight, removed from the paper filter and weighed again. The mass freezing loss was given by the difference in weight by percentage.

To evaluate the reheating loss samples were cut in $2.0 \times 2.0 \times 6.0 \mathrm{~cm}$, weighed and submerged for $6 \mathrm{~min}$ in $400 \mathrm{~mL}$ 
of boiling water in a beaker covered with a watch glass, and then drained on paper towels and cooled to $7{ }^{\circ} \mathrm{C}$ for $6 \mathrm{~min}$. The percentage of reheating loss was calculated as the difference in weight percentage (Hachmeister \& Herald, 1998).

The sliceability evaluation was performed using a commercial slicer (Arbel, São José do Rio Preto, Brazil): 10 slices of approximately $2 \mathrm{~mm}$ thickness were cut and evaluated for integrity using a 10 -point scale, with 10 being excellent slicing, and 0 being extremely poor slicing (with fully brittle slices). The results were expressed as a percentage of sliceability (O'Neill et al., 2003).

\subsection{Histological analysis}

The histological analysis was performed to evaluate the damage caused by freezing and thawing, and visible changes in the product structure due to the presence or absence of exudate. Samples of ham were fixed in $10 \%$ formalin and prepared following the stages of gradual dehydration, diaphanization, infiltration and embedment in paraffin according to the conventional technique cited by Junqueira \& Carneiro (2008). From each paraffin block, $4 \mu \mathrm{m}$ thick histological slides were obtained for later staining by hematoxylin-eosin. The analysis of histological sections was performed using light microscopy (Lambda LQT- 3, ATTO Instruments Co., Hong Kong, China) and the images were captured by the Motic Images Plus 2.0 software (Motic, Hong Kong, China). The histological specimen from each sample was evaluated using a 4 to 10 fold increase in objective lens and 10 fold increase eyepiece, providing a final magnification of 40 to 100 times.

\subsection{Sensory evaluation}

After approval by the Ethics Committee on Research involving Humans at the State University of Ponta Grossa (UEPG) (protocol \# 256 684), sensory evaluation was performed in individual cabins. Prior to the sensory analysis, products were analyzed microbiologically according to current legislation (Agência Nacional de Vigilância Sanitária, 2002) for thermotolerant coliforms at $45^{\circ} \mathrm{C}$; Salmonella sp; Coagulase positive Staphylococcus and sulphite reducing clostridia.
The initial group of assessors participating in the sensory analysis was composed of 172 individuals, in which $85 \%$ women and $15 \%$ men, aged between 18 and 67 . The assessors were previously selected using a ranking test, in which texture (softness) and salty taste were used to classify samples and to prove the evaluators' ability in differentiating samples (International Organization for Standardization, 2012). The 68 selected individuals were than assess the samples using the Multiple Comparison Test to softness and salty taste attribute.

The samples were prepared in $2 \mathrm{~cm}$ cubes, identified by random three-digit codes and served at temperatures below $10^{\circ} \mathrm{C}$. The Multiple Comparison Test was carried out separately to the parameters softness and salty taste. A nine-point scale was used in each test, with extremes of (1) being extremely less soft/ salty than the standard (control sample), and (9) being extremely softer/salty than the standard. The results were evaluated by two-factor analysis of variance (ANOVA) followed by the Dunnett's difference test (Meilgaard et al., 2006).

\subsection{Statistical analysis}

The results were expressed as mean \pm standard deviation. After undergoing testing for normality by the Shapiro-Wilk test and homogeneity of variance by Levene's test, the data were assessed by one-factor ANOVA followed by Fisher's test, when parametric, or Kruskal-Wallis test when non-parametric (Granato et al., 2014). The effects of the two freezing methods and the use of exudate were assesed by multiple regression analysis. For the statistical analysis, Statistica software version 7.0 (Statsoft Inc., Tulsa, USA) and Excel version 2010 (Microsoft, Redmond, WA, USA) were used (Nunes et al., 2015).

\section{Results and discussion}

\subsection{Physicochemical analysis}

The results of the physicochemical analysis of the cooked ham can be seen in Table 3. None of the evaluated physicochemical parameters showed a significant difference $(\mathrm{p}>0.05)$ in relation to the proposed changes in the raw material. This result is

Table 3. Physicochemical results (mean \pm sd) for cooked hams produced with meat frozen by different methods and for control sample.

\begin{tabular}{|c|c|c|c|c|c|c|}
\hline & SF1 & SF2 & FF1 & FF2 & $\mathrm{C}$ & $p$-value ${ }^{* *}$ \\
\hline $\mathrm{pH}$ & $6.25 \pm 0.01$ & $6.30 \pm 0.07$ & $6.35 \pm 0.03$ & $6.36 \pm 0.03$ & $6.34 \pm 0.09$ & 0.339 \\
\hline Moisture (g/100 g) & $74.19 \pm 1.57$ & $73.67 \pm 1.51$ & $74.62 \pm 1.81$ & $75.50 \pm 2.40$ & $75.31 \pm 1.98$ & 0.743 \\
\hline $\operatorname{Ash}(g / 100 \mathrm{~g})$ & $3.47 \pm 0.59$ & $3.55 \pm 0.70$ & $3.65 \pm 0.44$ & $3.58 \pm 0.58$ & $3.78 \pm 0.23$ & 0.977 \\
\hline Protein (g/100 g) & $18.33 \pm 1.39$ & $18.69 \pm 0.44$ & $18.11 \pm 1.03$ & $18.62 \pm 0.55$ & $18.42 \pm 0.81$ & 0.936 \\
\hline Water/protein ratio & $4.06 \pm 0.30$ & $3.94 \pm 0.13$ & $4.13 \pm 0.32$ & $4.06 \pm 0.20$ & $4.10 \pm 0.29$ & 0.919 \\
\hline Fat $(g / 100 \mathrm{~g})$ & $2.28 \pm 0.39$ & $2.42 \pm 0.15$ & $2.12 \pm 0.35$ & $1.63 \pm 0.40$ & $2.19 \pm 0.24$ & 0.093 \\
\hline Water activity & $0.984 \pm 0.003$ & $0.980 \pm 0.001$ & $0.981 \pm 0.005$ & $0.982 \pm 0.003$ & $0.981 \pm 0.003$ & 0.627 \\
\hline Sodium (g/100 g) & $1.19 \pm 0.11$ & $1.36 \pm 0.05$ & $1.19 \pm 0.15$ & $1.28 \pm 0.12$ & $1.18 \pm 0.03$ & 0.136 \\
\hline Nitrite (mg/kg) & $45.28 \pm 0.41$ & $45.60 \pm 0.50$ & $45.63 \pm 0.32$ & $45.05 \pm 0.23$ & $45.32 \pm 0.47$ & 0.404 \\
\hline$L^{*}$ & $66.11 \pm 2.85$ & $62.38 \pm 3.19$ & $64.29 \pm 3.16$ & $61.42 \pm 1.11$ & $65.55 \pm 2.89$ & 0.248 \\
\hline$a^{*}$ & $11.20 \pm 1.83$ & $12.71 \pm 0.51$ & $11.61 \pm 1.23$ & $12.75 \pm 0.42$ & $11.32 \pm 1.17$ & 0.337 \\
\hline$b^{*}$ & $11.00 \pm 0.48$ & $10.94 \pm 0.32$ & $10.90 \pm 1.11$ & $10.84 \pm 0.42$ & $9.67 \pm 0.14$ & 0.115 \\
\hline$C^{*}$ & $15.78 \pm 1.03$ & $16.79 \pm 0.60$ & $16.01 \pm 0.84$ & $16.77 \pm 0.10$ & $14.92 \pm 0.94$ & 0.072 \\
\hline $\mathrm{h}^{*}$ & $45.16 \pm 5.76$ & $40.92 \pm 0.19$ & $43.67 \pm 4.90$ & $41.65 \pm 2.96$ & $40.80 \pm 2.70$ & 0.656 \\
\hline
\end{tabular}

Note: SF1 - sample produced with frozen meat by slow process, without exudate; SF2 - sample produced with frozen meat by slow process, with exudate; FF1 - sample produced with frozen meat by fast process $\left(\mathrm{N}_{2}\right)$, without exudate; FF2 - sample produced with frozen meat by fast process, with exudate; $\mathrm{C}$ - sample produced with chilled meat. ${ }^{* *}$ Probability values obtained by one-way ANOVA. 
consistent with other studies on the effect of freezing on raw material in the production of ham. Peña et al. (1998) found no significant difference in water activity and moisture, and Utrera et al. (2012) observed no statistical difference in results related to moisture, protein, fat and $\mathrm{pH}$.

The $\mathrm{pH}$ of the samples showed no significant difference. The $\mathrm{pH}$ values were similar to those reported by Tomovic et al. (2013) from 6.20 to 6.25 for cooked ham with $20 \%$ injection. Li et al. (2011) found a mean $\mathrm{pH}$ of 6.24 for ham tumbled for 6 hours, which was similar to the tumbling time of our study. On the other hand, Peña et al. (1998) concluded that the $\mathrm{pH}$ of cooked ham produced with frozen/thawed meat showed significantly lower values than those of ham made with chilled meat.

The moisture content ranged from 73.67 to $75.50 \mathrm{~g} / 100 \mathrm{~g}$. Utrera et al. (2012) found no significant difference in moisture content in cooked hams with $20 \%$ injection, which was produced with fresh and frozen/thawed meat. Casiraghi et al. (2007) found values of moisture content of 66.1, 68.6 and $70.6 \mathrm{~g} / 100 \mathrm{~g}$ for ham with brine injections of 25, 30 and 35\%, respectively. The protein contents ranged from 18.11 to $18.69 \mathrm{~g} / 100 \mathrm{~g}$, which were similar to the values reported by Casiraghi et al. (2007) for cooked ham with $25 \%$ injection, and by Tomovic et al. (2013) for ham with $20 \%$ injection.

The lipid content ranged from 1.63 to $2.42 \mathrm{~g} / 100 \mathrm{~g}$, which was consistent with values reported by Los et al. (2014) for cooked hams produced in Brazil (0.89 to $3.57 \mathrm{~g} / 100 \mathrm{~g}$ ). Válková et al. (2007) found values ranging from 1.56 to $4.04 \mathrm{~g} / 100 \mathrm{~g}$, and the average value of fat content reported by Cheng et al. (2005) was $1.89 \mathrm{~g} / 100 \mathrm{~g}$. Utrera et al. (2012) reported that the fat content of cooked ham presented significant difference in relation to the leg muscle used for processing and not in relation to the use of frozen/thawed meat compared to fresh meat.

In the present study, the sodium content of the samples ranged from 1.18 to $1.36 \mathrm{~g} / 100 \mathrm{~g}$. Multiple regression analysis coupled with ANOVA showed that the exudate factor had a significant effect $(p=0.023$ ) on sodium (Table 4 ), while the freezing and the combined effect of exudate and freezing had no impact on sodium level. Peña et al. (1998) reported that ham produced with frozen/thawed meat showed a lower salt content than ham produced with fresh meat.

The residual values of nitrite, which were analyzed 30 days after production, ranged from 45.05 to $45.63 \mathrm{mg} / \mathrm{kg}$. According to Hustad et al. (1973), after the addition of nitrite to meat its concentration immediately decreases by $16 \%$ and during processing a further $51 \%$ is lost. At the end of the process only
$33 \%$ of the amount that was initially added remains. The loss of nitrite is influenced by the composition of the product, processing, storage temperature and $\mathrm{pH}$.

There was no statistical difference between the color parameters evaluated in the produced ham. The $L^{*}$ values that were found ranged from 61.42 to 66.11 , similar to those reported by Válková et al. (2007), which were from 61.57 to 65.79 , and Li et al. (2011), which were 61.80.

\subsection{Rheological analysis}

Table 5 shows the results of the rheological characterization of the samples. The control sample (C) showed significantly lower value for hardness and was softer compared to the others. Among the samples that used frozen meat, it can be seen that the SF1 sample showed the highest value for hardness, followed by the FF1 sample, but these two samples did not differ significantly. The incorporation of exudate released upon thawing decreased the hardness value of the SF2 and FF2 samples when compared to samples in which exudate was not used, i.e. samples SF1 and FF1. This result shows that fresh meat provides softness in ham, but the use of frozen meat with the incorporation of exudate could also be an interesting alternative for processing. This result was expected, due to the fact that it is generally agreed that chilled meat shows better WHC because it has not suffered damage to muscle fibers from freezing, i.e. it has the ability to retain its own water and also absorbs brine more effectively than meat submitted to freezing (Wirth et al., 1981).

Chewiness, which is a parameter calculated from hardness, presented similar results. Utrera et al. (2012) demonstrated that, hardness, as well as chewiness, increased in ham produced with frozen and thawed meat compared to ham made with chilled meat.

The absence of significant difference in the hardness of the samples produced with meat submitted to slow freezing (SF1) and fast freezing (FF1) can be attributed to recrystallization during storage, i.e. the increase of small ice crystals formed by fast freezing (Bevilacqua \& Zaritzky, 1982). Ngapo et al. (1999) studied the effect of different freezing rates in pork meat and concluded that the crystals formed reached a peak in size during slow freezing, however, small crystals formed during rapid freezing achieved this peak by recrystallization. According to Mortensen et al. (2006), small ice crystals formed by rapid freezing may undergo recrystallization and increase in size during storage at temperatures of $-20^{\circ} \mathrm{C}$.

The compression force and shear force showed no significant differences between the samples by ANOVA. However, multiple regression analysis (Table 4$)$ showed that the exudate $(\mathrm{p}=0.036)$

Table 4. Effect of freezing and use of exudate on cooked ham's characteristics.

\begin{tabular}{|c|c|c|c|c|c|c|}
\hline \multirow{2}{*}{ Efects } & \multicolumn{3}{|c|}{ Sodium level } & \multicolumn{3}{|c|}{ Compression force } \\
\hline & Effect & Standard error & $p$-value & Effect & Standard error & $p$-value \\
\hline Mean/Interaction & 1.229 & 0.027 & $<0.001$ & 48.168 & 3.796 & $<0.001$ \\
\hline (1) Freezing & -0.065 & 0.060 & 0.298 & -3.001 & 8.489 & 0.730 \\
\hline (2) Exudate & 0.157 & 0.060 & $0.023^{\star}$ & -20.25 & 8.489 & $0.036^{\star}$ \\
\hline $1 \times 2$ & -0.015 & 0.060 & 0.799 & -19.41 & 8.489 & $0.043^{*}$ \\
\hline
\end{tabular}

Note: ${ }^{\star}$ significant at $95 \%$ of confidence. 
Table 5. Rheological characterization results of ham samples produced with meat subjected to different freezing methods and with chilled meat.

\begin{tabular}{|c|c|c|c|c|c|c|}
\hline Parameters & SF1 & SF2 & FF1 & FF2 & $\mathrm{C}$ & ANOVA \\
\hline Hardness $(\mathrm{N})$ & $18.75^{\mathrm{a}} \pm 1.18$ & $15.94^{b} \pm 2.65$ & $16.39^{\mathrm{ab}} \pm 0.82$ & $15.11^{\mathrm{b}} \pm 0.58$ & $12.46^{c} \pm 0.22$ & $0.003^{*}$ \\
\hline Adhesiviness (N.mm) & $-0.09 \pm 0.01$ & $-0.05 \pm 0.02$ & $-0.20 \pm 0.14$ & $-0.11 \pm 0.07$ & $-0.1 \pm 0.08$ & 0.512 \\
\hline Elasticity $(\mathrm{mm})$ & $0.86 \pm 0.00$ & $0.86 \pm 0.08$ & $0.87 \pm 0.02$ & $0.91 \pm 0.05$ & $0.89 \pm 0.01$ & 0.508 \\
\hline Cohesiviness $^{1}$ & $0.76 \pm 0.01$ & $0.80 \pm 0.06$ & $0.82 \pm 0.04$ & $0.83 \pm 0.04$ & $0.78 \pm 0.01$ & 0.247 \\
\hline Chewiness (N.mm) & $12.36^{\mathrm{a}} \pm 0.87$ & $10.67^{b} \pm 0.16$ & $11.61^{\mathrm{ab}} \pm 0.36$ & $11.29^{\mathrm{ab}} \pm 0.90$ & $8.58^{c} \pm 0.09$ & $<0.001^{\star}$ \\
\hline Resilience $^{1}$ & $0.40 \pm 0.01$ & $0.45 \pm 0.08$ & $0.47 \pm 0.07$ & $0.50 \pm 0.06$ & $0.42 \pm 0.02$ & 0.219 \\
\hline Compression force $(\mathrm{N})$ & $50.7 \pm 6.58$ & $49.86 \pm 17.65$ & $67.10 \pm 20.30$ & $27.44 \pm 19.13$ & $45.73 \pm 6.69$ & 0.104 \\
\hline Shear force $(\mathrm{N})$ & $25.06 \pm 2.84$ & $32.51 \pm 10.23$ & $27.73 \pm 12.15$ & $17.64 \pm 6.23$ & $30.99 \pm 3.44$ & 0.234 \\
\hline WHC (\%) & $97.58 \pm 0.57$ & $97.84 \pm 0.24$ & $98.23 \pm 0.08$ & $98.50 \pm 0.54$ & $97.89 \pm 0.87$ & 0.316 \\
\hline Syneresis (\%) & $5.20 \pm 0.78$ & $4.47 \pm 0.76$ & $4.69 \pm 0.35$ & $4.03 \pm 0.80$ & $5.16 \pm 0.79$ & 0.302 \\
\hline Freezing loss (\%) & $9.97^{\mathrm{a}} \pm 1.45$ & $6.80^{c} \pm 0.27$ & $9.08^{\mathrm{ab}} \pm 0.66$ & $7.35^{\mathrm{bc}} \pm 1.02$ & $8.89^{\mathrm{ab}} \pm 1.30$ & $0.02^{\star}$ \\
\hline Heating loss (\%) & $15.62 \pm 1.81$ & $16.17 \pm 2.74$ & $16.04 \pm 1.95$ & $16.61 \pm 2.20$ & $15.82 \pm 1.30$ & 0.979 \\
\hline Cooling loss (\%) & $12.18^{\mathrm{a}} \pm 1.27$ & $11.53^{\mathrm{a}} \pm 1.31$ & $12.63^{\mathrm{a}} \pm 1.11$ & $12.88^{\mathrm{a}} \pm 0.87$ & $6.69^{\mathrm{b}} \pm 0.89$ & $0.002^{*}$ \\
\hline Slicing ${ }^{2}$ & $8.33 \pm 1.53$ & $7.67 \pm 0.58$ & $7.67 \pm 0.58$ & $8.33 \pm 1.53$ & $9.67 \pm 0.58$ & 0.268 \\
\hline
\end{tabular}

Note: SF1 - sample produced with frozen meat by slow process, without exudate; SF2 - sample produced with frozen meat by slow process, with exudate; FF1 - sample produced with frozen meat by fast process $\left(\mathrm{N}_{2}\right)$, without exudate; $\mathrm{FF} 2$ - sample produced with frozen meat by fast process, with exudate; $\mathrm{C}$ - sample produced with chilled meat. ${ }^{*}$ significant at $95 \%$. different letters at the same row shown different samples. ${ }^{1}$ adimensional parameters. ${ }^{2} 0$ to 10 score. WHC - water holding capacity.

and the combined effect of exudate and freezing $(\mathrm{p}=0.043)$ influenced negatively the compression force of hams.

Cooling losses showed significantly higher results for samples prepared from frozen meat. This can be explained by the fact that frozen meat retains less water in the protein matrix compared to chilled meat. This is due to shrinkage caused in the myofibrillar proteins, which reduces the capillary forces that maintain the water that is bound in the inter-filamentary spaces (Liu et al., 2000). The increase in solute concentration during freezing leads to denaturation of sarcoplasmic proteins, which influence the retention of water during the post-thaw process (Leygonie et al., 2012).

WHC as well as syneresis, freezing loss, heating loss, and slicing did not significantly differ between themselves (Table 5). Even with the loss of sarcoplasmic proteins in frozen and thawed meats (Savage et al., 1990) according to Schmidt (1994), this type of protein has less influence on the binding formation than myofibrillar proteins. According to Tornberg (2005), myofibrillar proteins, especially myosin, have a high gel forming ability even in low concentrations (from $0.5 \%$ ), while sarcoplasmic proteins require a concentration of $3.0 \%$ to bind meat products. These parameters may also have been influenced by adding ingredients that improve the binding characteristics of the product (Pietrasik et al., 2007; Hsu \& Sun, 2006), such as carrageenan and soy protein isolate, and by tumbling action which extracts myofibrillar proteins (Tornberg, 2005).

These results are interesting from the industrial and technological points of view because they demonstrate the possibility of using frozen meat (either by the slow or fast method) when it is thawed at $5{ }^{\circ} \mathrm{C}$, in cooked ham production without resulting in a loss in product quality.

\subsection{Histological analysis}

Figure 1 shows photomicrographs of samples which demonstrate the changes in the tissues caused by freezing and thawing of the meat. The control sample (C) showed a more integral and cohesive protein matrix structure with intact muscle fibers, similar to the results reported by Prestes et al. (2013) for chicken ham.

The SF1 sample showed unstructured muscle tissue with cells dispersed in the extracellular matrix. Intact muscle cells could be seen next to the dispersed cells, but all were with cytoplasmic striations, indicating that, as expected, slow freezing caused changes in cellular structure. The SF2 sample showed organized muscle tissue with intact muscle cells of normal appearance alongside cells with cytoplasmic striations (edema).

The FF1 sample was characterized by large, well-connected, swollen muscle cells and cytoplasm with intense cross-striation, apparently with edema. There was little interstitial adipose tissue and the presence of unstructured connective tissue around the muscle tissue. It was expected that the meat frozen by the fast method would present small ice crystals and uniform cell structure, and this appearance was perceived in the FF1 sample. However, the appearance of large muscle cells may be explained by the storage of the meat at a higher temperature $\left(-18^{\circ} \mathrm{C}\right)$ than the freezing temperature by liquid nitrogen, causing recrystallization of ice crystals (Mortensen et al., 2006). The FF2 sample showed well organized muscle tissue in lobules of normal aspect. The muscle cells had distinct striations and slightly less intensity than the FF1 sample, with small areas of breakdown.

From these results it is possible to say that the control sample (C) showed better muscle structure and that there was a change in the cellular structure of the SF1 and FF1 samples, and to a lesser extent in the SF2 and FF2 samples. The latter was possibly due to the reincorporation of exudate and the effect of tumbling (Katsaras \& Budras, 1993). The damage observed in the photomicrographs of the samples produced with meat subjected to freezing can be correlated to the higher degree of hardness, as shown in Table 5.

The use of exudate, which is composed mainly of sarcoplasmic proteins, represented largely by myoglobin, can also explain 
the deeper color in the photomicrographs of the SF2 and FF2 samples compared with the SF1 and FF1 samples.

\subsection{Sensory evaluation}

Softness and salty taste were the evaluated attributes, which were related to compression force and sodium content, respectively, for which there was a significant effect of using the exudate. Despite the fact that the results for instrumental texture presented significantly different values for hardness (Table 5), and the control sample showed a better structural aspect according to histological analysis (Figure 1), no statistical differences were perceived in the sensory evaluation between the treatments and the control, according to the Dunnett test (data not shown), both in terms of softness and salty taste.

Utrera et al. (2012) reported that the difference in hardness and chewiness of hams produced with frozen/thawed meat was perceived by trained evaluators in a sensory panel. In the present study, sensory analysis indicated that the substitution of chilled meat by frozen/thawed meat, with or without the incorporation of exudate, did not influence the perception of softness and salty taste.
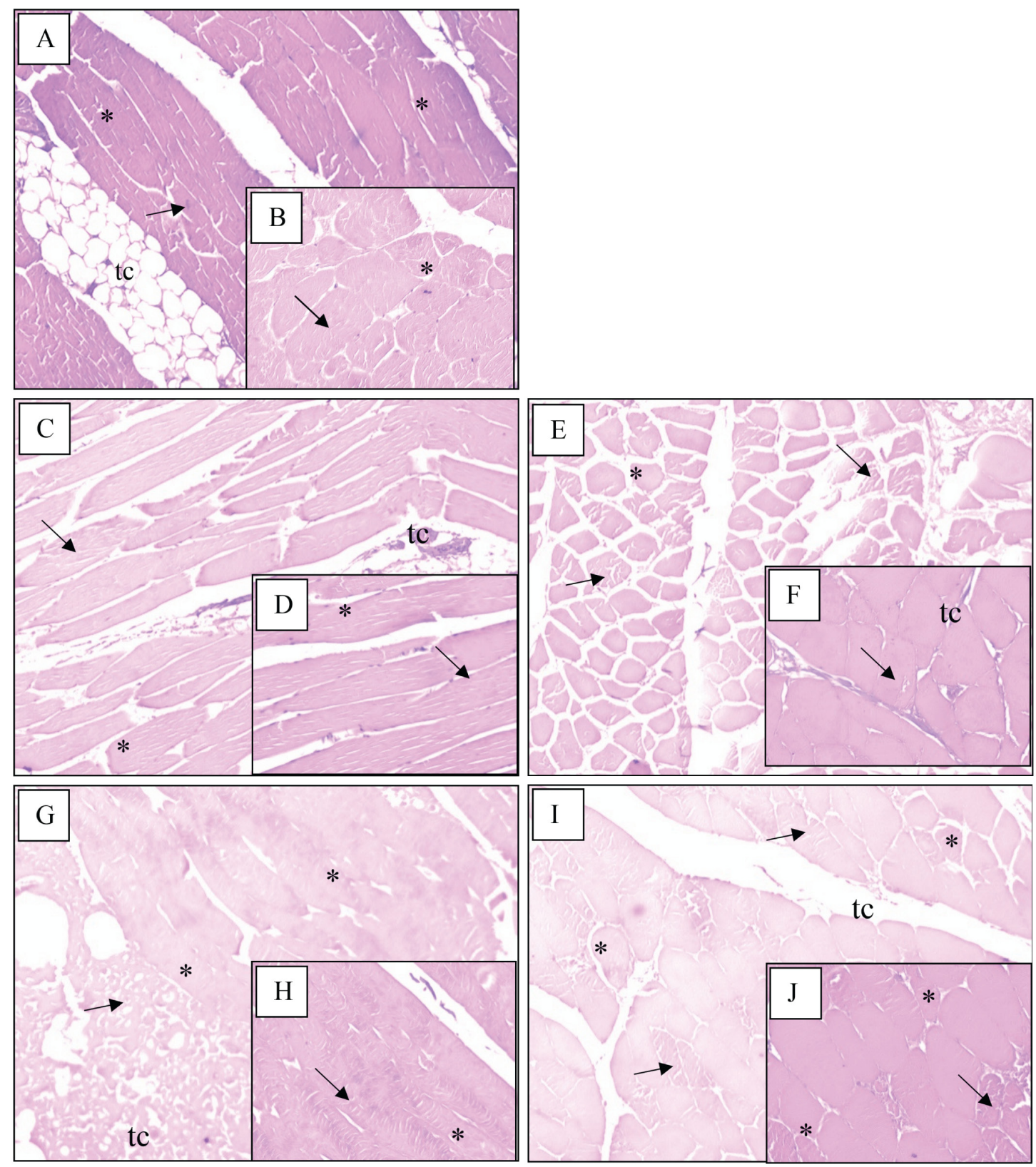

Figure 1. Cooked hams' samples photomicrographs, with details on the right. Note: A and B - control sample (C); C and D - SF1 - sample produced with frozen meat by slow process, without exudate; E and F - SF2 - sample produced with frozen meat by slow process, with exudate; $\mathrm{G}$ and $\mathrm{H}$ - FF1 - sample produced with frozen meat by fast process $\left(\mathrm{N}_{2}\right)$, without exudate; I and J - FF2 - sample produced with frozen meat by fast process, with exudate. $\mathrm{tc}=$ conective tissue; arrow $=$ cell striation. ${ }^{*}=$ normal aspect cell. Zoom: $40 \times$ e $100 \times$. 


\section{Conclusion}

Changes in the texture profile and the cooling losses were detected in the ham samples produced with frozen/thawed meat, whereas the water holding capacity (WHC), syneresis, freezing loss, heating loss and slicing of the ham samples did not differ significantly. By using light microscopy analysis it was possible to observe changes in the tissues due to freezing and thawing the raw materials. The effect of the exudate was significant only in terms of the compression force and sodium content parameters; however, these differences were not perceived by the sensory analysis. Considering the results obtained, the technical viability of using frozen/thawed meat in cooked hams was proved, regardless of the considered method of freezing. The possibility of using frozen/thawed meat in the production of cooked ham increases flexibility within processing plants without changes in expected product quality.

\section{Acknowledgements}

The authors are grateful to CAPES (Pos-doctoral fellowship - Daniel Granato and a Master scholarship - Francine Gomes Basso Los), CNPq (Reseacrher grant - Ivo Mottin Demiate) and Fundação Araucária for the financial support.

\section{References}

Association of Analytical Chemists - AOAC. (1990). Official methods of analysis of the Association of Analytical Chemists (40th ed.). Washington, DC: AOAC.

Agência Nacional de Vigilância Sanitária - ANVISA. (2002, January 2). Regulamento técnico sobre padrões microbiológicos para alimentos. (RDC n¹2, de 2 de Janeiro de 2002). Diário Oficial [da] República Federativa do Brasil.

Bevilacqua, A. E., \& Zaritzky, N. E. (1982). Ice recrystallization in frozen beef. Journal of Food Science, 47(5), 1410-1414. http://dx.doi. org/10.1111/j.1365-2621.1982.tb04950.x.

Brasil. Ministério da Agricultura, Pecuária e Abastecimento. (1995, November 1). Normas técnicas de instalações e equipamentos para abate e industrialização de suínos. (Portaria $\mathrm{n}^{\circ} 711$, de $1^{\circ} \mathrm{de}$ novembro de 1995). Diário Oficial [da] República Federativa do Brasil.

Casiraghi, E., Alamprese, C., \& Pompei, C. (2007). Cooked ham classification on the basis of brine injection level and pork breeding country. LWT: Food Science and Technology, 40, 164-169. http:// dx.doi.org/10.1016/j.lwt.2005.07.007.

Cheng, Q., Sun, D.-W., \& Scannell, A. G. M. (2005). Feasibility of water cooking for pork ham processing as compared with traditional dry and wet air cooking methods. Journal of Food Engineering, 67(4), 427-433. http://dx.doi.org/10.1016/j.jfoodeng.2004.05.011.

Estevez, M. (2011). Protein carbonyls in meat systems: a review. Meat Science, 89(3), 259-279. http://dx.doi.org/10.1016/j.meatsci.2011.04.025. PMid:21621336.

Granato, D., Calado, V. M. A., \& Jarvis, B. (2014). Observations on the use of statistical methods in Food Science and Technology. Food Research International, 55, 137-149. http://dx.doi.org/10.1016/j. foodres.2013.10.024.

Hachmeister, K. A., \& Herald, T. J. (1998). Thermal and reological properties and textural atributes of reduced-fat turkey batters. Poultry Science, 77(4), 632-638. http://dx.doi.org/10.1093/ps/77.4.632. PMid:9565249.
Hsu, K. Y., \& Sun, L. Y. (2006). Comparisons on 10 non-meat protein fat substitutes for low-fat Kung-wans. Journal of Food Engineering, 74(1), 47-53. http://dx.doi.org/10.1016/j.jfoodeng.2005.02.022.

Hustad, G. O., Cerveny, J. G., Trenk, H., Deibel, R. H., Kautter, D. A., Fazio, T., Johnston, R. W., \& Kolari, O. E. (1973). Effect of sodium nitrite and sodium nitrate on botulinal toxin production and nitrosamine formation in wieners. Applied Microbiology, 26(1), 22-26. PMid:4580194.

International Organization for Standardization - ISO. (2012). ISO 8586: sensory analysis: general guidelines for selection, training and monitoring of selected and expert assessors. Geneva: ISO.

Junqueira, L. C., \& Carneiro, J. (2008). Histologia básica. São Paulo: Guanabara Koogan.

Katsaras, K., \& Budras, K.-D. (1993). The relationship of the microstructure of cooked ham to its properties and quality. LWT: Food Science and Technology (Campinas.), 26(3), 229-234. http://dx.doi.org/10.1006/ fstl.1993.1050.

Lachowicz, K., Sobczak, M., Gajowieck, L., \& Zych, A. Z. (2003). Effects of massaging time on texture, rheological properties, and structure of three pork ham muscles. Meat Science, 63(2), 225-233. http://dx.doi.org/10.1016/S0309-1740(02)00073-6. PMid:22062182.

Lee, M. H., Baek, M. H., Cha, D. S., Park, H. J., \& Lim, S. T. (2002). Freeze-thaw stabilization of sweet potato starch gel by polysaccharide gums. Food Hydrocolloids, 16(4), 345-352. http://dx.doi.org/10.1016/ S0268-005X(01)00107-2.

Leygonie, C., Britz, T. J., \& Hoffman, L. C. (2012). Meat quality comparison between fresh and frozen/thawed ostrich M. Iliofibularis. Meat Science, 91(3), 364-368. http://dx.doi.org/10.1016/j.meatsci.2012.02.020. PMid:22405875.

Li, B., \& Sun, D. W. (2002). Novel methods for rapid freezing and thawing of foods: a review. Journal of Food Engineering, 54(3), 175182. http://dx.doi.org/10.1016/S0260-8774(01)00209-6.

Li, C., Szczepaniak, S., Steen, L., Goemaere, O., Impens, S., Paelinck, H., \& Zhou, G. (2011). Effect of tumbling time and cooking temperature on quality attributes of cooked ham. International Journal of Food Science \& Technology, 46(10), 2159-2163. http:// dx.doi.org/10.1111/j.1365-2621.2011.02731.x.

Liu, G., Xiong, Y. L., \& Butterfield, D. A. (2000). Chemical, physical, and gel-forming properties of oxidized myofibrils and whey- and soy-protein isolates. Journal of Food Science, 65(5), 811-818. http:// dx.doi.org/10.1111/j.1365-2621.2000.tb13592.x.

Los, F. G. B., Granato, D., Prestes, R. C., \& Demiate, I. M. (2014). Characterization of commercial cooked hams according to physicochemical, sensory, and textural parameters using chemometrics. Food Science and Technology (Campinas.), 34(3), 577-584. http:// dx.doi.org/10.1590/1678-457x.6423.

Meilgaard, M. C., Carr, B. T., \& Civille, G. V. (2006). Sensory evaluation techniques (4th ed., pp. 117-121). Boca Raton: CRC Press.

Mortensen, M., Andersen, H. J., Engelsen, S. A., \& Bertram, H. C. (2006). Effect of freezing temperature, thawing and cooking rate on water distribution in two pork qualities. Meat Science, 72(1), 34-42. http://dx.doi.org/10.1016/j.meatsci.2005.05.027. PMid:22061371.

Ngapo, T. M., Babare, I. H., Reynolds, J., \& Mawson, R. F. (1999). Freezing and thawing rate effects on drip loss from samples of pork. Meat Science, 53(3), 149-158. http://dx.doi.org/10.1016/S03091740(99)00050-9. PMid:22063195.

Nunes, C. A., Alvarenga, V. O., Souza Sant'Ana, A., Santos, J. S., \& Granato, D. (2015). The use of statistical software in food science and technology: advantages, limitations and misuses. Food 
Research International, 75, 270-280. http://dx.doi.org/10.1016/j. foodres.2015.06.011.

O’Neill, D. J., Lynch, P. B., Troy, D. J., Buckley, D. J., \& Kerry, J. P. (2003). Effects of PSE on the quality of cooked hams. Meat Science, 64(2), 113-118. http://dx.doi.org/10.1016/S0309-1740(02)00117-1. PMid:22062856.

Pedroso, R. A., \& Demiate, I. M. (2008). Avaliação da influência de amido e carragena nas características físico-químicas e sensoriais de presunto cozido de peru. Ciência Tecnologia de Alimentos, 28(1), 24-31. http://dx.doi.org/10.1590/S0101-20612008000100005.

Peña, M. M., Cid, M. C., \& Bello, J. A. (1998). Method for identification of frozen meat used for production of cooked ham. Meat Science, 48(3-4), 257-264. http://dx.doi.org/10.1016/S0309-1740(97)001022. PMid:22063074.

Pietrasik, Z., Jarmoluk, A., \& Shand, P. J. (2007). Effect of non-meat proteins on hydration and textural properties of pork meat gels enhanced with microbial transglutaminase. LWT: Food Science and Technology (Campinas.), 40, 915-920. http://dx.doi.org/10.1016/j. lwt.2006.03.003.

Prestes, R. C., Graboski, A., Roman, S. S., Kempka, A. P., Toniazzo, G., Demiate, I. M., \& Di Luccio, M. (2013). Effects of the addition of collagen and degree of comminution in the quality of chicken ham. Journal of Applied Poultry Research, 22(4), 885-903. http://dx.doi. org/10.3382/japr.2013-00809.

Prestes, R. C., Carneiro, E. B., \& Demiate, I. M. (2012). Hydrolyzed collagen, modified starch and guar gum addition in turkey ham. Ciência Rural, 42(7), 1307-1313. http://dx.doi.org/10.1590/S010384782012005000037.

Savage, A. W. J., Warriss, P. D., \& Jolley, P. D. (1990). The amount and composition of the proteins in drip from stored pig meat. Meat Science, 27(4), 289-303. http://dx.doi.org/10.1016/0309-1740(90)90067-G. PMid:22055365.
Schmidt, G. R. (1994). Comportamento funcional de los componentes de la carne durante el processado. In J. F. Price \& B. S. Schweigert. Ciencia de la carne y de los productos carnicos (2nd ed., pp. 377-391). Zaragoza: Acribia.

Tabilo, G., Flores, M., Fiszman, S. M., \& Toldrá, F. (1999). Postmortem meat quality and sex affect textural properties and protein breakdown of dry-cured ham. Meat Science, 51(3), 255-260. http://dx.doi. org/10.1016/S0309-1740(98)00125-9. PMid:22061860.

Terra, N. N. (2000). Apontamentos de tecnologia de carnes (pp. 151162). São Leopoldo: Unisinos.

Tomovic, V. M., Jokanovic, M. R., Petrovic, L. S., Tomovic, M. S., Tasic, T. A., Ikonic, P. M., Sumic, Z. M., Sojic, B. V., Skaljac, S. B., \& Soso, M. M. (2013). Sensory, physical and chemical characteristics of cooked ham manufactured from rapidly chilled and earlier deboned M. semimembranosus. Meat Science, 93(1), 46-52. http://dx.doi. org/10.1016/j.meatsci.2012.07.015. PMid:22910801.

Tornberg, E. (2005). Effects of heat on meat proteins: implications on structure and quality of meat products. Meat Science, 70(3), 493-508. http://dx.doi.org/10.1016/j.meatsci.2004.11.021. PMid:22063748.

Utrera, M., Armenteros, M., Ventanas, S., Solano, F., \& Estévez, M. (2012). Pre-freezing raw hams affects quality traits in cooked hams: potential influence of protein oxidation. Meat Science, 92(4), 596-603. http://dx.doi.org/10.1016/j.meatsci.2012.06.005. PMid:22748310.

Válková, V., Saláková, A., Buchtová, H., \& Tremlová, B. (2007). Chemical, instrumental and sensory characteristics of cooked pork ham. Meat Science, 77(4), 608-615. http://dx.doi.org/10.1016/j. meatsci.2007.05.013. PMid:22061949.

Wirth, F., Leistner, L., \& Rodel, W. (1981). Valores normativos de la tecnologia carnica (pp. 42-88). Zaragoza: Acribia.

Xia, X., Kong, B., Liu, Q., \& Liu, J. (2009). Physicochemical change and protein oxidation in porcine longissimus dorsi as influenced by different freeze-thaw cycles. Meat Science, 83(2), 239-245. http:// dx.doi.org/10.1016/j.meatsci.2009.05.003. PMid:20416749. 